\title{
Paper-derived cobalt and nitrogen co-doped carbon nanotube@porous carbon as a nonprecious metal electrocatalyst for the oxygen reduction reaction
}

\author{
Gaopeng Liu a, Bin Wang a , Li Xu a , Penghui Ding a , Pengfei Zhang b,c, Jiexiang Xia a,b,*, Huaming Li a,\#, \\ Junchao Qian ${ }^{\mathrm{B}}$ \\ a School of Chemistry and Chemical Engineering, Institute for Energy Research, Jiangsu University, Zhenjiang 212013, Jiangsu, China \\ b Chemical Sciences Division, Oak Ridge National Laboratory, Oak Ridge 37830, USA \\ ' School of Chemistry and Chemical Engineering, Shanghai Jiao Tong University, Shanghai 200240, China \\ d Jiangsu Key Laboratory for Environment Functional Materials, Suzhou University of Science and Technology, Suzhou 215009, Jiangsu, China
}

\section{A R T I C L E I N F}

\section{Article history:}

Received 21 November 2017

Accepted 23 December 2017

Published 5 April 2018

\section{Keywords:}

Oxygen reduction reaction

Waste paper

Biomass

Porous carbon

Cobalt

\begin{abstract}
A B S T R A C T
The oxygen reduction reaction (ORR) is a vitally important process in fuel cells. The development of high-performance and low-cost ORR electrocatalysts with outstanding stability is essential for the commercialization of the electrochemical energy technology. Herein, we report a facile synthesis of cobalt (Co) and nitrogen (N) co-doped carbon nanotube@porous carbon (Co/N/CNT@PC-800) electrocatalyst through a one-step pyrolysis of waste paper, dicyandiamide, and cobalt(II) acetylacetonate. The surface of the hierarchical porous carbon supported a large number of carbon nanotubes (CNTs), which were derived from dicyandiamide through the catalysis of Co. The addition of Co resulted in the formation of a hierarchical micro/mesoporous structure, which was beneficial for the exposure of active sites and rapid transportation of ORR-relevant species $\mathrm{CO}_{2}, \mathrm{H}^{+}, \mathrm{OH}^{-}$, and $\mathrm{H}_{2} \mathrm{O}$ ). The doped $\mathrm{N}$ and Co formed more active sites to enhance the ORR activity of the electrocatalyst. The Co/N/CNT@PC-800 material exhibited optimal ORR performance with an onset potential of $0.005 \mathrm{~V}$ vs. $\mathrm{Ag} / \mathrm{AgCl}$ and a half-wave potential of $-0.173 \mathrm{~V}$ vs. $\mathrm{Ag} / \mathrm{AgCl}$. Meanwhile, the electrocatalyst showed an excellent methanol tolerance and a long-term operational durability than that of $\mathrm{Pt} / \mathrm{C}$, as well as a quasi-four-electron reaction pathway. The low-cost and simple synthesis approach makes the Co/N/CNT@PC-800 a prospective electrocatalyst for the ORR. Furthermore, this work provides an alternative approach for exploring the use of biomass-derived electrocatalysts for renewable energy applications.
\end{abstract}

(C) 2018, Dalian Institute of Chemical Physics, Chinese Academy of Sciences. Published by Elsevier B.V. All rights reserved.

\section{Introduction}

Fuel cells are one of the most promising energy conversion devices for providing sustainable and clean energy [1,2]. The oxygen reduction reaction (ORR) is the cathode reaction in fuel cells and is usually catalyzed by precious metals, especially by state-of-the-art platinum (Pt)-based catalysts, because of their excellent catalytic performance [3]. However, the Pt materials

\footnotetext{
*Corresponding author. Tel: +86-511-88791108; E-mail: xjx@ujs.edu.cn

\# Corresponding author. Tel: +86-511-88791108; E-mail: lhm@ujs.edu.cn

This work was supported by the National Nature Science Foundation of China $(21476098,21471069,21576123)$ and International Postdoctoral Exchange Fellowship Program of China Postdoctoral Council (20150060).

DOI: 10.1016/S1872-2067(17)62982-6 | http://www.sciencedirect.com/science/journal/18722067 | Chin. J. Catal., Vol. 39, No. 4, April 2018
} 
are expensive and suffer from limited natural reserves, sluggish kinetics, poor durability, the crossover effect, and low tolerance to methanol, which pose a key obstacle to its development and commercialization [4-7]. Therefore, the development of low-cost, high-performance non-Pt catalysts to replace Pt-based catalysts is considered as one of the best ways to achieve large-scale commercialization of fuel cells.

To endow non-Pt catalysts with superior ORR performance, various carbon-based materials are a great choice. Carbon-based materials have some unmatched versatility for electrocatalysis including good electrical conductivity, chemical inertness, versatile morphology, and large surface area. Various carbon-based materials have been extensively applied for the ORR such as graphene [8], carbon nanotubes (CNTs) [9], and carbon microspheres [10]. However, pure carbon materials have few active sites and display poor ORR activity. Numerous studies have demonstrated that the doping of heteroatoms (B $[11,12], \mathrm{N}[13,14], \mathrm{P}[15,16], \mathrm{S}[17,18])$ within the skeleton of carbon materials can change their electron donor properties and form active sites to boost the ORR $[19,20]$. Specifically, $\mathrm{N}$-doped carbon materials with unique structures, favorable flexibility, and excellent mechanical and electrochemical properties have been widely used as effective electrocatalysts for the ORR [21]. In N-modified carbon materials, the nitrogen atoms have a higher electronegativity than that of the carbon atoms. The electron density of the carbon atoms adjacent to the nitrogen atom is lowered, which favors the dissociative chemisorption of oxygen [22]. Furthermore, the earth-abundant transition metals (Fe [23], Co [24], $\mathrm{Ni}$ [25], $\mathrm{Cu}$ [26]) have also been introduced to enhance ORR activity, which could immobilize the dissociative oxygen species and promote electrical conductivity $[23,27]$. In particular, transition metals (such as Co) in N-doped carbon can effectively improve the ORR properties by constructing Co- $\mathrm{N}_{x}$ active sites [28]. Cao et al. [29] synthesized Co and N co-doped bamboo-like CNTs (NBCNT), which showed an enhanced ORR performance compared with individual Co- or $\mathrm{N}$-doped materials. The synergistic effect of the co-doped Co and N promoted the ORR process.

Recently, carbon-based materials derived from carbon-enriched biomass (seaweed [30], fermented rice [31], typha orientalis [32]) have also been widely exploited for the ORR. Biomass is sustainable, renewable, ecofriendly, cheap, and ubiquitous in nature. All these merits imply that biomass is a potential candidate for the ORR for large-scale applications. Paper is one of the most common biomass-derived materials used in daily human life, but its recycling rate is still very low. Wei et al. [33] have prepared Fe-based N-doped carbon materials as ORR catalysts using tissue and filter paper. Carbon materials prepared from waste paper have a large specific surface area. The large specific surface area is favorable for the transmission of ORR-related species $\left(\mathrm{O}_{2}, \mathrm{H}^{+}, \mathrm{OH}^{-}\right.$, and $\left.\mathrm{H}_{2} \mathrm{O}\right)$ and accelerates the reaction rate. Furthermore, it is an environmentally friendly process, which would not only reduce the cost but would also be conducive to large-scale preparation.

Herein, we designed a readily scalable approach for the fabrication of $\mathrm{Co}$ and $\mathrm{N}$ co-doped porous carbon (Co/N/CNT@PC-800) electrocatalysts, which were prepared through a simple annealing of a mixture of waste paper, dicyandiamide, and cobalt(II) acetylacetonate at $800{ }^{\circ} \mathrm{C}$. Because of the catalytic effect of cobalt, the Co/N/CNT@PC-800 catalyst with a porous structure had many nanotubes on its surface. The numerous micropores and mesopores are beneficial for exposure of the active sites and the transportation of ORR-relevant species. The Co and N co-doped carbon materials can generate more active sites to enhance the ORR activity. For these reasons, the low-cost catalyst exhibited good ORR performance with a quasi-four-electron reaction pathway, good stability, and methanol tolerance in an alkaline medium. This work will open up a new way to utilize biomass waste to obtain value-added materials through an economic and environmentally friendly method.

\section{Experimental}

\subsection{Chemicals}

Cobalt(II) acetylacetonate (99\%), dicyandiamide, and methanol were obtained from Sinopharm Chemical Reagent Co., Ltd. (Shanghai, China). Nafion (10\% wt\%) was obtained from Sigma-Aldrich (Missouri, USA). Commercial $20 \mathrm{wt} \% \mathrm{Pt} / \mathrm{C}$ was obtained from Alfa Aesar (China) Chemicals Co., Ltd. (Shanghai, China). The waste paper obtained from our laboratory. (Zhenjiang, China). All these chemicals were used as delivered without further treatment.

\subsection{Material synthesis}

The shredded paper was washed with an appropriate amount of distilled water to remove the impurities. Then, the paper pulp was filtered by suction and vacuum dried at $60{ }^{\circ} \mathrm{C}$ before further use.

The synthesis of Co/N/CNT@PC-800 is shown in Scheme 1. In a typical synthesis, $2.0 \mathrm{~g}$ dicyandiamide and $0.5 \mathrm{~g}$ of cobalt(II) acetylacetonate were dissolved in $50 \mathrm{~mL}$ methanol and defined as solution A. Then, $1.0 \mathrm{~g}$ pretreated paper was distributed in $50 \mathrm{~mL}$ of distilled water to obtain mixture B. Solution A was added into mixture B and then stirred for $12 \mathrm{~h}$. The intermediate product was dried in an oven. Afterwards, the obtained dark-green material was ground and placed into a ceramic boat. The material was heated to $500{ }^{\circ} \mathrm{C}$ for $2 \mathrm{~h}$ with a ramp rate of $5{ }^{\circ} \mathrm{C} \mathrm{min}-1$ under an argon atmosphere in a tubular furnace. Then, the temperature was raised to $800{ }^{\circ} \mathrm{C}$ and main-

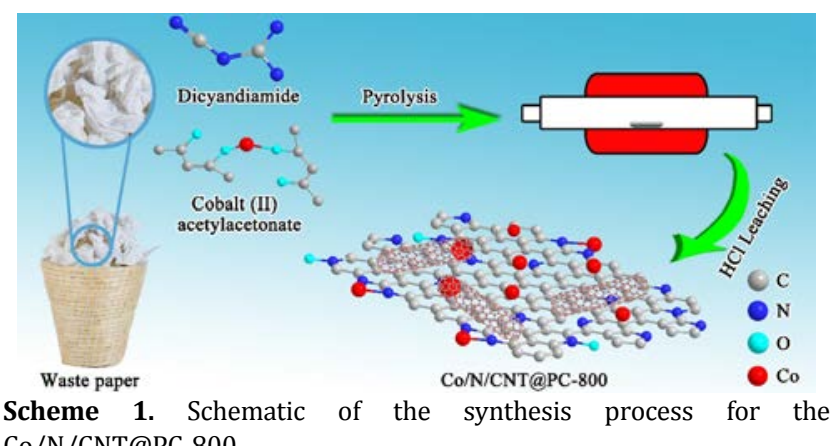
Co/N/CNT@PC-800. 
tained for $2 \mathrm{~h}$. Finally, the carbon composite was immersed in 6 mol $\mathrm{L}^{-1} \mathrm{HCl}$ for $12 \mathrm{~h}$ to remove any unstable and inactive species.

$\mathrm{C}-800$ was fabricated by using the same procedure as that for Co/N/CNT@PC-800 without adding cobalt(II) acetylacetonate and dicyandiamide.

$\mathrm{N} / \mathrm{C}-800$ was fabricated by using the same procedure as that for Co/N/CNT@PC-800 without adding cobalt(II) acetylacetonate.

Co/PC-800 was fabricated by using the same procedure for Co/N/CNT@PC-800 without adding dicyandiamide.

\subsection{Material characterization}

The morphology and microstructure of the materials were verified by scanning electron microscopy (SEM; JEOLJSM-7001F) and transmission electron microscopy (TEM; JEOL6JEM-2010). The elemental composition of the electrocatalysts was determined by element mapping (JSM-6010PLUS/LA). The crystalline structures of the products were recorded with a Shimadzu XRD-6000 X-ray diffractometer in the $2 \theta$ range of $10^{\circ}-80^{\circ}$ with $\mathrm{Cu} K_{\alpha}$ radiation at room temperature $(\lambda=0.15418 \mathrm{~nm})$. The surface states of the samples were analyzed by X-ray photoelectron spectroscopy (XPS) with a monochromatic $\mathrm{Mg} K_{\alpha}$ source operated at $20 \mathrm{kV}$. The specific surface area and pore size distribution of the products were measured by adsorption-desorption isotherms of $\mathrm{N}_{2}$ on a TriStar II 3020 surface area and porosity analyzer (Micromeritics Instrument Corporation, USA). The Raman spectra were obtained with a micro Raman spectrometer (Renishaw Invia) in a backscattering geometry with a $532 \mathrm{~nm}$ laser as the excitation source.

\subsection{Electrochemical measurements}

The ORR experiments were performed in a three-electrode cell connected to an electrochemical analyzer (CHI 760E) at room temperature. A rotating disk electrode (RDE, $3 \mathrm{~mm}$ diameter), Pt wire, and $\mathrm{Ag} / \mathrm{AgCl}$ electrodes were used as working electrode, counter electrode, and reference electrode, respectively. $4 \mathrm{mg}$ of prepared catalyst was distributed in $1 \mathrm{~mL}$ mixed solvent (2-propanol/water $=1: 3(v / v)$ ) with $15 \mu \mathrm{L}$ of $10 \%$ Nafion. $20 \mu \mathrm{L}$ of the catalyst ink was loaded on the surface of the $\mathrm{RDE}$ and dried at room temperature. Cyclic voltammetry (CV) measurements were recorded at $50 \mathrm{mV} \mathrm{s}^{-1}$ from 0.2 to $-0.8 \mathrm{~V}$ vs. Ag/AgCl. Linear sweep voltammetry (LSV) measurements were performed at a rotating speed from 400 to $2500 \mathrm{r} \mathrm{min}^{-1}$ at $5 \mathrm{mV} \mathrm{s}^{-1}$ in $0.1 \mathrm{~mol} \mathrm{~L}^{-1} \mathrm{KOH}$ solution. $\mathrm{O}_{2}$ or $\mathrm{N}_{2}$ were introduced into the electrolyte $30 \mathrm{~min}$ before the test.

Koutecky-Levich (K-L) plots were analyzed at different rotation speeds of the ORR polarization curves. The electron transfer number $(n)$ was calculated by using the K-L equation [34]:

$$
\begin{gathered}
\frac{1}{j}=\frac{1}{j_{k}}+\frac{1}{j_{L}}=\frac{1}{j_{k}}+\frac{1}{B \omega^{1 / 2}} \\
B=0.62 n F C_{\mathrm{O}_{2}} D_{\mathrm{O}_{2}}{ }^{2 / 3} v^{-1 / 6}, J_{K}=n F k C_{\mathrm{O}_{2}} \\
J_{K}=n F k C_{\mathrm{O}_{2}}
\end{gathered}
$$

in which $J$ is the measured current density, $J_{k}$ and $J_{L}$ are the kinetic- and diffusion-limiting current densities, respectively. $B$ is the Levich slope, $\omega$ is the angular velocity, $F$ is the Faraday constant $\left(F=96485 \mathrm{C} \mathrm{mol}^{-1}\right), C_{\mathrm{O}_{2}}$ is the concentration of dissolved $\mathrm{O}_{2}\left(C_{\mathrm{O}_{2}}=1.2 \times 10^{-6} \mathrm{~mol} \mathrm{~cm}^{-3}\right), D_{\mathrm{O}_{2}}$ is the diffusion coefficient of $\mathrm{O}_{2}$ in $0.1 \mathrm{~mol} \mathrm{~L}^{-1} \mathrm{KOH}\left(D_{\mathrm{O}_{2}}=1.9 \times 10^{-5} \mathrm{~cm}^{2} \mathrm{~s}^{-1}\right), v$ is the kinetic viscosity of the electrolyte $\left(v=0.01 \mathrm{~cm}^{2} \mathrm{~s}^{-1}\right)$, and $k$ is the electron transfer rate constant.

Rotating ring-disk electrode (RRDE) measurements: In the RRDE system, the rotating speed of the working electrode was fixed at $1600 \mathrm{r} \mathrm{min}^{-1}$ with a scan rate of $5 \mathrm{mV} \mathrm{s}^{-1}$. The potential of the ring electrode was set to $0.5 \mathrm{~V}$ vs. $\mathrm{Ag} / \mathrm{AgCl}$. The electron transfer number and hydrogen peroxide yields were calculated by the following equations [35]:

$$
\begin{gathered}
n=\frac{4 I_{D}}{I_{D}+I_{R} / N} \\
\%\left(\mathrm{H}_{2} \mathrm{O}_{2}\right)=200 \times \frac{I_{R} / N}{I_{D}+I_{R} / N}
\end{gathered}
$$

in which $I_{D}$ and $I_{R}$ are the disk and ring currents and $N$ is the collection efficiency, which was reported to be $42.4 \%$ by the manufacturer.

\section{Results and discussion}

The SEM and TEM images were used to elucidate the morphology and microstructure of the prepared samples. As shown in Fig. S1(a) and (b), C-800 and N/C-800 exhibited a similar microstructure with a wrinkled surface. This indicated that the introduction of dicyandiamide did not change the original microstructure of the waste paper. After the addition of Co, many pore structures appeared on the surface of the Co/PC-800 catalyst (Fig. S1(c) and (d)). Therefore, the doped Co played a critical role in the formation of the porous structures. As shown in Fig. 1(a) and (b), the surface of the Co/N/CNT@PC-800 catalyst had a porous structure and many carbon nanotubes with diameters of approximately $20 \mathrm{~nm}$. The synergetic coupling of doped Co and $\mathrm{N}$ was essential for the formation of carbon nanotubes [29]. As shown in Fig. 1(c) and (d),
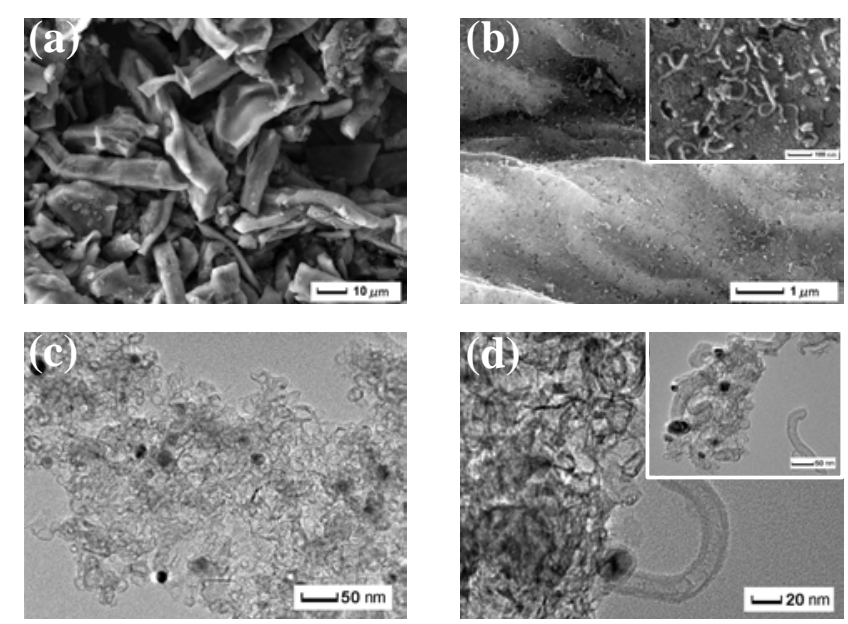

Fig. 1. SEM (a, b) and TEM (c, d) images of the Co/N/CNT@PC-800 catalyst. 
Co/N/CNT@PC-800 had an obvious hollow tube structure and some residual Co nanoparticles were wrapped in the carbon layer and CNTs. Moreover, the element mapping ascertained that both Co and $\mathrm{N}$ were uniformly distributed in the Co/N/CNT@PC-800 catalyst (Fig. S2).

The crystal structure of the C-800, N/C-800, Co/PC-800 and Co/N/CNT@PC-800 catalysts was further characterized by powder X-ray diffraction (XRD) patterns (Fig. 2(a)). The well-defined diffraction peaks of the XRD patterns of the Co/N/CNT@PC-800 and Co/PC-800 catalysts at approximately $2 \theta=44.2^{\circ}, 51.5^{\circ}, 75.9^{\circ}$ were assigned to the (111), (200), (200) plane of $\mathrm{Co}$ [28]. All the carbon materials showed a sharp peak corresponding to the (002) plane of the graphite structure. In stark contrast, the C-800 catalyst displayed a broad peak at approximately $23.7^{\circ}$, which signified a low graphitization degree in this sample [36]. Raman spectra were obtained to further analyze the graphitization degree and defects of these catalysts (Fig. 2(b)). The peaks at approximately $1350 \mathrm{~cm}^{-1}$ (D-band), $1580 \mathrm{~cm}^{-1}$ (G-band), and $2680 \mathrm{~cm}^{-1}$ (2D-band) in the Raman spectra indicated a typical characteristic signature of crystalline graphite $[37,38]$. The G-band indicated the presence of $s p^{2}$-hybridized carbon atoms. The presence of defects in the doped carbon materials was indicated by the D-band [39]. The relative intensities of the G-band $\left(I_{\mathrm{G}}\right)$ and D-band $\left(I_{\mathrm{D}}\right)$ were used to study the characteristics of the carbon materials. A lower $I_{\mathrm{D}} / I_{\mathrm{G}}$ ratio indicates a higher degree of graphitization of carbon materials [40]. As displayed in Fig. 2(b), the $I_{\mathrm{D}} / I_{\mathrm{G}}$ values of the C-800, N/C-800, Co/PC-800, and Co/N/CNT@PC-800 catalysts were $0.98,1.02,1.10$, and 1.04 , respectively. The increase in defects and disorder for N/C-800, Co/PC-800, and Co/N/CNT@PC-800 after Co or N doping was clearly observed. The $I_{\mathrm{D}} / I_{\mathrm{G}}$ ratio of the Co/N/CNT@PC-800 catalyst was lower than that of $\mathrm{Co} / \mathrm{PC}-800$. This may be owing to the formation of a large number of carbon nanotubes, which further improved
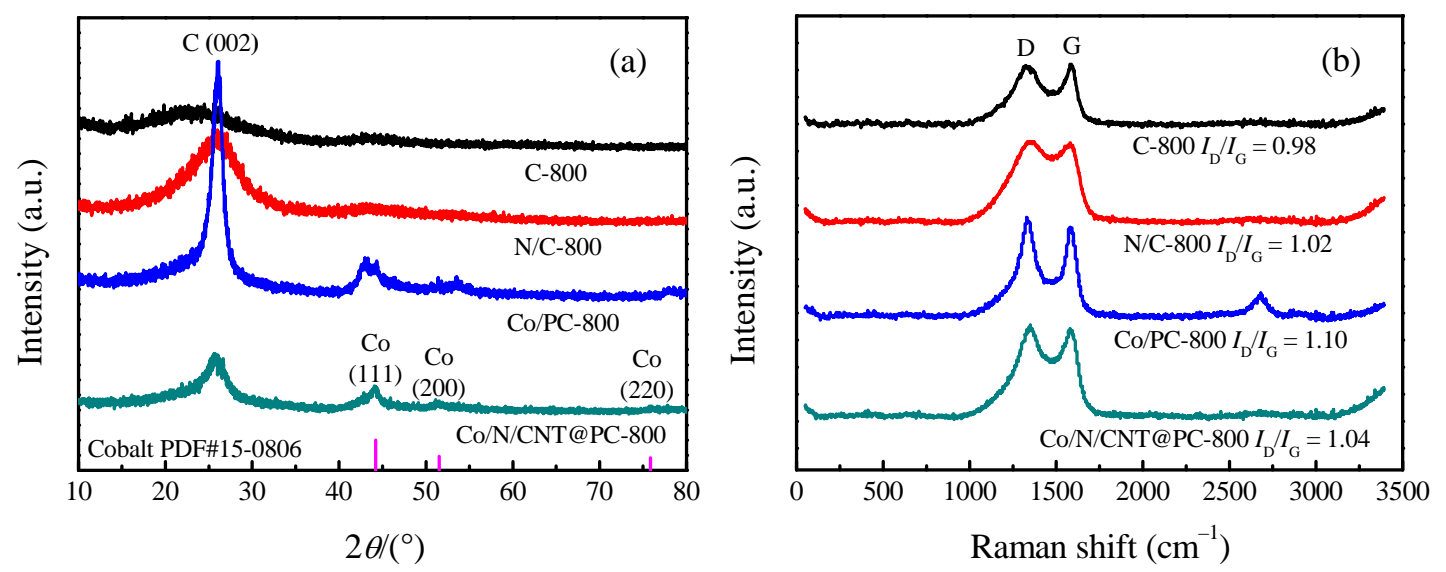

Fig. 2. XRD patterns (a) and Raman spectra (b) of C-800, N/C-800, Co/PC-800 and Co/N/CNT@PC-800 catalysts.
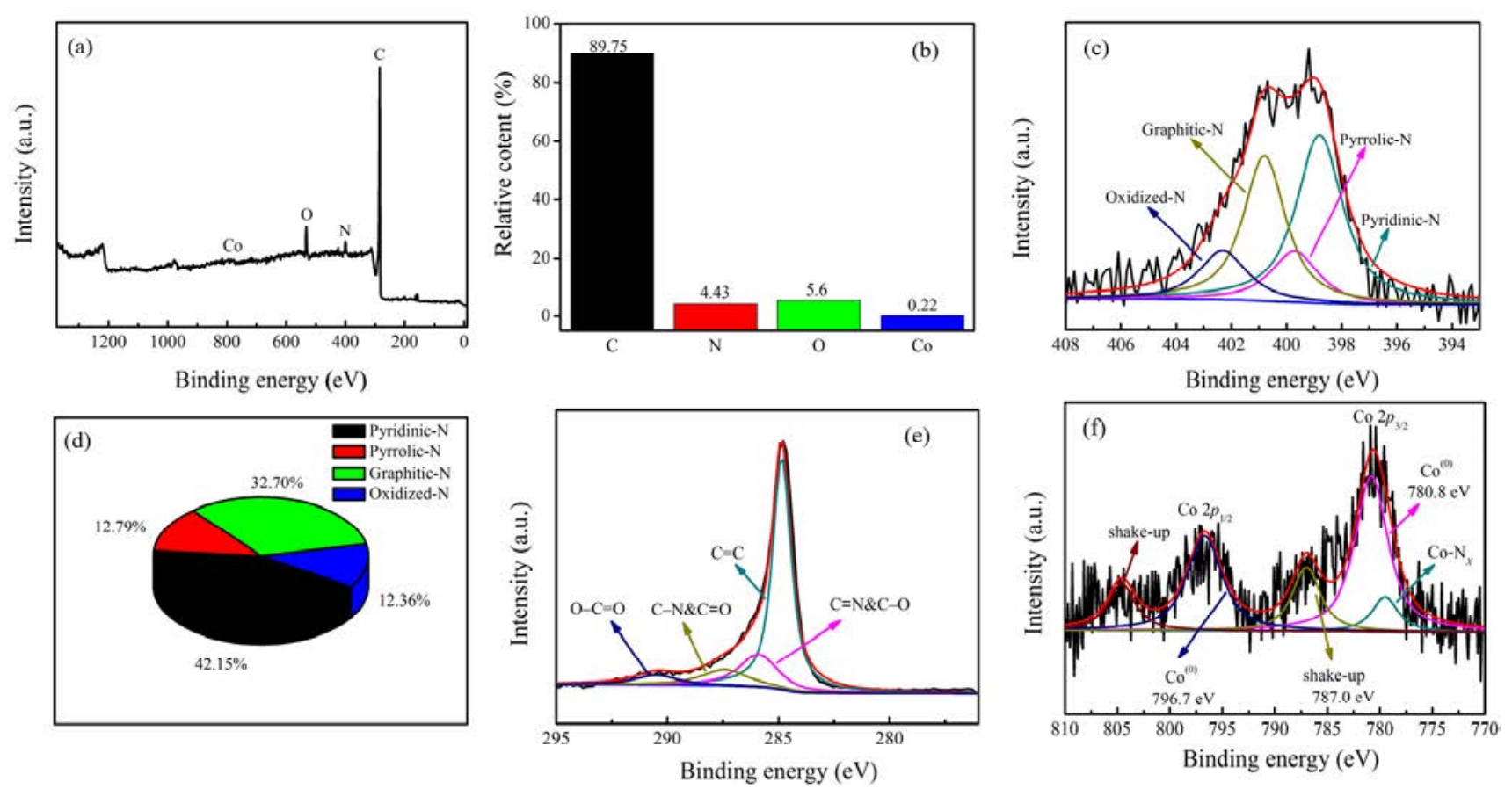

Fig. 3. (a) Wide XPS survey of Co/N/CNT@PC-800. (b) Element contents for C, N, O, Co from XPS data. High-resolution spectra of N 1s (c), C 1s (e), Co $2 p$ (f). The proportion of $\mathrm{N}$ with different chemical states (d). 
the graphitization degree.

XPS measurements were performed to further elaborate the doped element and bonding states. The survey XPS spectrum of the Co/N/CNT@PC-800 catalyst demonstrated the presence of C (89.75 at\%), N (4.43 at\%), O (5.6 at\%), Co (0.22 at\%) (Fig. $3(\mathrm{a})$ and (b)). The high-resolution $\mathrm{N} 1 s$ spectrum showed four peaks at $398.45 \pm 0.3,399.53 \pm 0.3,400.73 \pm 0.3$, and $402.50 \pm$ $0.3 \mathrm{eV}$, which were pyridinic-N (42.15\%), pyrrolic-N (12.79\%), graphitic-N (32.70\%), and oxidized-N (12.36\%), respectively (Fig. 3(c), 3(d) and S3). This suggested that pyridinic-N and graphitic- $\mathrm{N}$ were the dominant species, which has been demonstrated to boost $\mathrm{O}_{2}$ reduction [41]. As shown in Fig. 3(e), there were four types of bonding states in the $\mathrm{C} 1 \mathrm{~s}$ spectrum: $\mathrm{C}$ $=C, C=N \& C-O, C=0 \& C-N$, and $O=C-O$, which indicated the existence of $\mathrm{N}$ and $\mathrm{O}$ heteroatoms in the hybrids. The high-resolution spectrum of Co $2 p_{3 / 2}$ and Co $2 p_{1 / 2}$ can be fitted with three components in accordance with $\mathrm{Co}^{(0)}, \mathrm{Co}-\mathrm{N}_{x}$ and the shake-up peaks (Fig. 3(f)). The peaks at 780.8 and $796.7 \mathrm{eV}$ were assigned to the zerovalent state cobalt, which was consistent with the results of the XRD. The peak at $779.5 \mathrm{eV}$ was the Co- $\mathrm{N}_{x}$ peak, which demonstrated the existence of a coordination bond between Co and $\mathrm{N}$ atoms [28].

The specific surface area and pore size of the hybrids were determined by the nitrogen adsorption isotherms. The surface area of the Co/N/CNT@PC-800, Co/PC-800, N/C-800, and C-800 catalysts was $421.146,304.801,358.220$ and $476.675 \mathrm{~m}^{2}$ $\mathrm{g}^{-1}$ respectively (Fig. 4 and Table S1). The type IV isotherm with a distinct hysteresis loop in the medium-and high-pressure regions $\left(P / P_{0}=0.4-1.0\right)$ implied the presence of multiple micropores and mesopores in the structure of the prepared catalysts. The pore size distributions diagrams (inset) indicated that the size of the micro/mesopores was between 1 and 10 $\mathrm{nm}$. The number of mesopores increased after doping of Co. The results also confirmed the appearance of the porous structure in the SEM patterns after the doping of Co, which indicated that the Co was beneficial for the formation of a porous structure. It has been reported that a hierarchical porosity is favorable for mass transfer of ORR-related species and the formation of abundant active sites for ORR [42].

The ORR activities of the Co/N/CNT@PC-800, Co/PC-800, N/C-800 and C-800 catalysts were investigated by rotating disk electrode measurements. Fig. S4(a) and (b) showed the cyclic voltammogram tests of the Co/N/CNT@PC-800 and Pt/C catalysts in a $\mathrm{O}_{2}$-saturated and $\mathrm{N}_{2}$-saturated solution. No cathodic peaks could be observed in the $\mathrm{N}_{2}$-saturated solution for the two samples. In contrast, when the electrolyte solution was saturated with $\mathrm{O}_{2}$, cathodic peaks appeared for those catalysts in the $\mathrm{CV}$ potential range, demonstrating the ORR activity of the catalysts, which was attributed to the reduction of $\mathrm{O}_{2}$. As presented in Fig. 5(a), Co/N/CNT@PC-800 showed a better oxygen reduction performance with a more positive onset potential, half-wave potential $\left(E_{1 / 2}\right)$, and higher limited current density than the other three prepared materials (Table S2). Compared with the C-800 curve, the N/C-800 showed a more positive
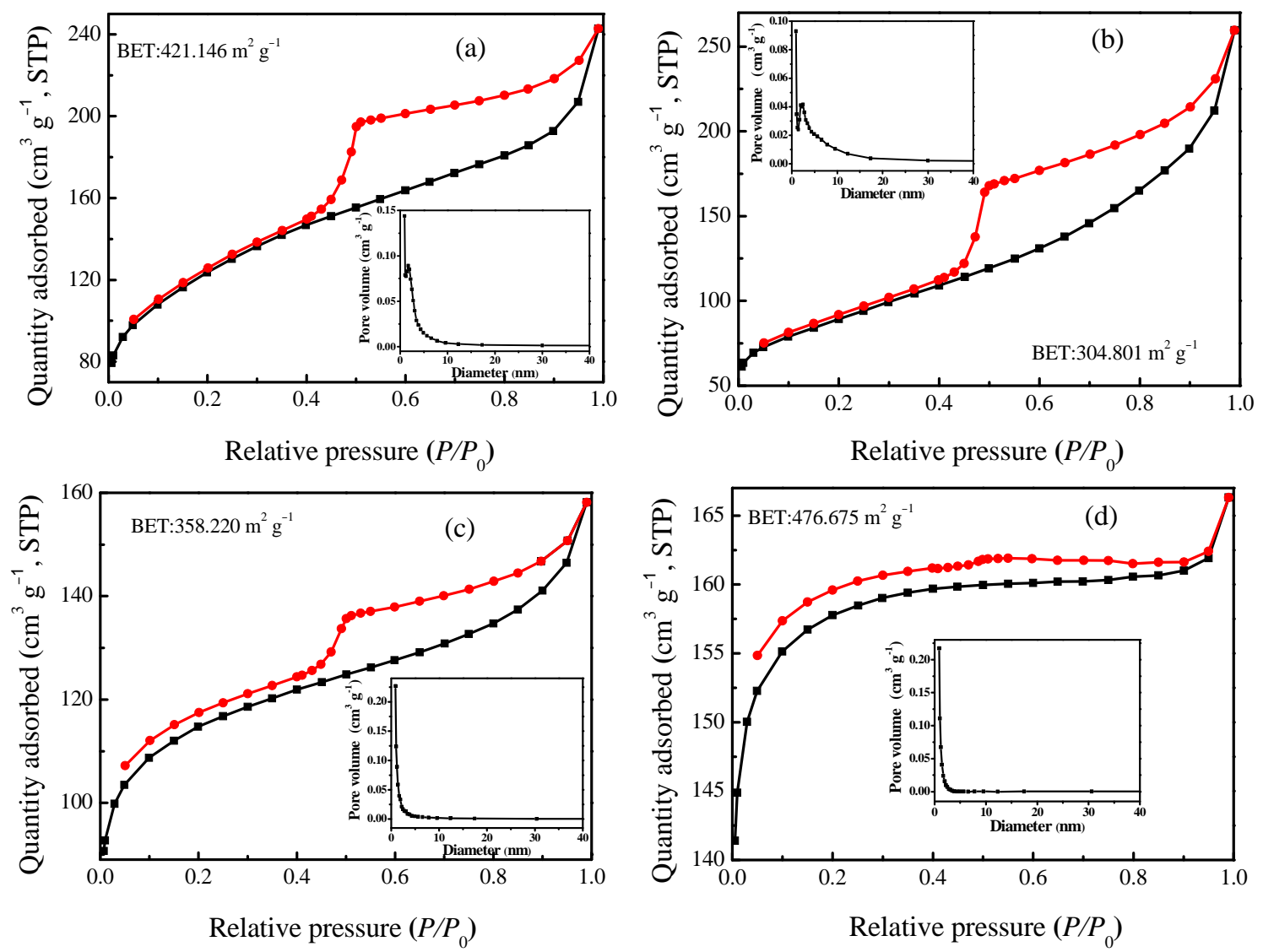

Fig. 4. $\mathrm{N}_{2}$ adsorption-desorption isotherms (the inset: the corresponding pore size distribution) of Co/N/CNT@PC-800 (a), Co/PC-800 (b), N/C-800 (c) and C-800 (d) catalysts. 

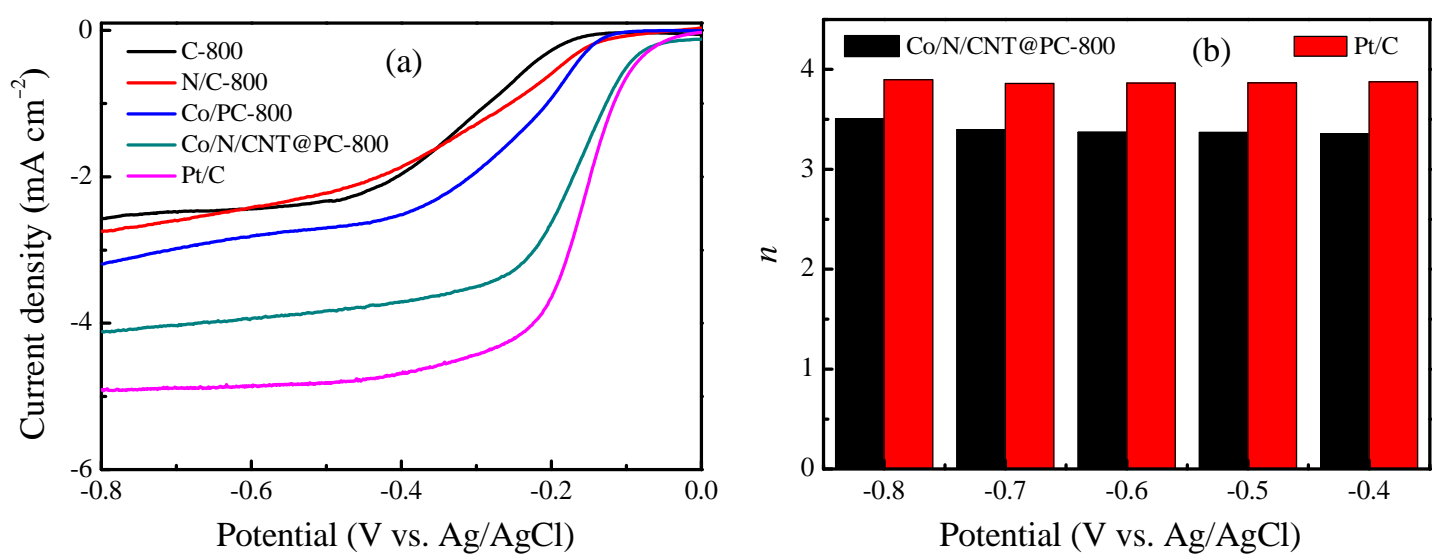

Fig. 5. (a) Linear scan voltammograms of C-800, N/C-800, Co/PC-800, Co/N/CNT@PC-800 and Pt/C catalysts in $\mathrm{O}_{2}$-saturated 0.1 mol $\mathrm{L}^{-1} \mathrm{KOH}$ at a rotation rate of $1600 \mathrm{r} \mathrm{min}^{-1}$ with a scan rate of $5 \mathrm{mV} \mathrm{s}^{-1}$. (b) Electron transfer number of Co/N/CNT@PC-800 and Pt/C catalysts.

initial potential and the Co/PC-800 displayed a more positive initial potential and higher limited current density. This indicated that the N- or Co-doped carbon materials can boost the ORR properties, but the activity promotion was limited. The Co/N/CNT@PC-800 possessed optimized ORR activity than that of Co or N single-doped materials, which was owing to the synergetic interaction between both $\mathrm{N}$ and Co co-doped in the carbon materials. The Co/N/CNT@PC-800 catalyst showed a superior ORR performance than most catalysts derived from biomass under similar conditions (Table S2). The (K-L) plots of the Co/N/CNT@PC-800 and Pt/C catalysts were obtained from the LSV curves at different rotation speeds; both showed a good linearity (Fig. S5(c) and (d)). The electron transfer number of the Co/N/CNT@PC-800 catalyst was calculated to be approximately 3.4-3.5 at potentials ranging from -0.4 to $-0.8 \mathrm{~V}$ (Fig. 5(b)). The result suggested that the Co/N/CNT@PC-800 exhibited a quasi-four-electron pathway in the ORR process. All the results indicated that both the Co- and the $\mathrm{N}$-functionalized carbon species were essential for the active site in $\mathrm{M}-\mathrm{N}_{x} / \mathrm{C}$ type catalysts [43].
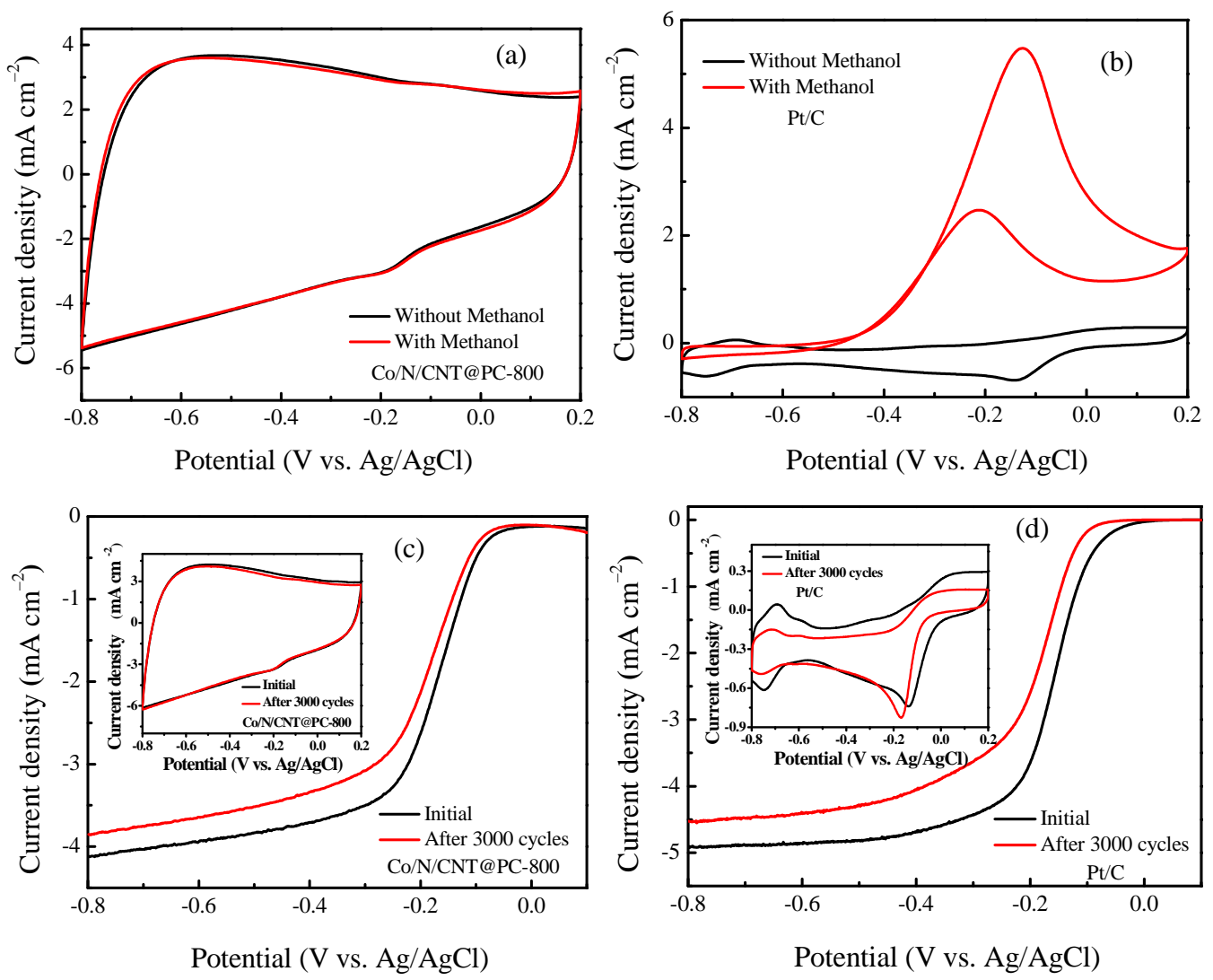

Fig. 6. $(\mathrm{a}, \mathrm{b})$ Cyclic voltammograms of Co/N/CNT@PC-800 and Pt/C catalysts in $\mathrm{O}_{2}$-saturated 0.1 mol L-1 KOH without any methanol and with methanol at a scan rate of $50 \mathrm{mV} \mathrm{s}^{-1}$. (c, d) Linear scan voltammograms (the inset: cyclic voltammograms) of Co/N/CNT@PC-800 and Pt/C catalysts for ORR in $\mathrm{O}_{2}$-saturated $0.1 \mathrm{~mol} \mathrm{~L}^{-1} \mathrm{KOH}$ before and after 3000 cycles. 
The tolerance to methanol and stability are significant criteria to evaluate the performance of an ORR catalyst. As shown in Fig. 6(a) and (b), after the addition of methanol $\left(1 \mathrm{~mol} \mathrm{~L}^{-1}\right)$, the CV curve of the Pt/C catalyst clearly changed and displayed a typical inverse methanol oxidation peak. However, there was only a slight effect on the CV curve of the Co/N/CNT@PC-800 catalyst. The results showed that the Co/N/CNT@PC-800 catalyst had a tolerance to methanol. Finally, the durability tests of the Co/N/CNT@PC-800 and Pt/C catalysts were recorded by performing 3000 cycles of cyclic voltammogram measurements in $\mathrm{O}_{2}$-saturated $0.1 \mathrm{~mol} \mathrm{~L}^{-1} \mathrm{KOH}$ with a scan rate of $50 \mathrm{mV} \mathrm{s}^{-1}$. The Co/N/CNT@PC-800 catalyst could maintain high activity with a limited current density loss of $0.27 \mathrm{~mA} \mathrm{~cm}^{-2}$ and there was no significant change in the initial potential (Fig. 6(c)). Nevertheless, the limited current density of the Pt/C catalyst showed a decrease of approximately $0.80 \mathrm{~mA} \mathrm{~cm}-2$ at $-0.8 \mathrm{~V}$, and the initial potential became more negative (Fig. 6(d)). In addition, the $E_{1 / 2}$ of the Co/N/CNT@PC-800 catalyst showed a negative shift of $15 \mathrm{mV}$, which was much smaller than that of commercial Pt/C $\left(\Delta E_{1 / 2}=37 \mathrm{mV}\right)$. As shown in the inset of Fig. 6(c), a well-defined reduction peak in the $\mathrm{CV}$ curves of Co/N/CNT@PC-800 was still evident after 3000 cycles. However, the peak potential of Pt/C shifted negatively from -0.138 to $-0.168 \mathrm{~V}$, almost $30 \mathrm{mV}$ (inset of Fig. $6(\mathrm{~d})$ ). These results indicated that the Co/N/CNT@PC-800 demonstrated a more remarkable methanol crossover effect and long-term stability for the ORR.
To further study the ORR performance of Co/N/CNT@PC-800 in an alkaline environment, rotating ring-disk electrode (RRDE) measurements were performed to investigate the electron transfer number and $\mathrm{H}_{2} \mathrm{O}_{2}$ yield. Fig. 7 recorded the ring (Fig. 7(a)) and disk (Fig. 7(b)) currents of the Co/N/CNT@PC-800 and Pt/C catalysts. The limiting current of Co/N/CNT@PC-800 was $-553 \mu \mathrm{A}$ at $-0.8 \mathrm{~V}$, which was slightly different from that of $\mathrm{Pt} / \mathrm{C}(-625 \mu \mathrm{A})$. The electron transfer number and the $\mathrm{H}_{2} \mathrm{O}_{2}$ yield was directly calculated from the disk currents and the ring currents by Eqs. (4) and (5), respectively. As shown in Fig. 7, the electron transfer number of the Co/N/CNT@PC-800 and Pt/C catalysts was approximately 3.5-3.7 and 3.8-3.9 (Fig. 7(c)), respectively. The $\mathrm{H}_{2} \mathrm{O}_{2}$ yields of the Co/N/CNT@PC-800 and Pt/C catalysts were 26.6\% and

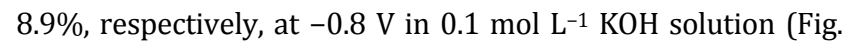
7 (d)). All the electrochemical experiments suggested that the oxygens were directly reduced to hydroxyls through a quasi-four-electron reaction in the ORR process and the Co/N/CNT@PC-800 is a good choice as a cathode catalyst.

Based on above results, the Co/N/CNT@PC-800 catalyst showed an optimized ORR performance, which illustrated the mechanism controlling the ORR active sites in the electrocatalyst. First, doped N could improve the electron donor-acceptor properties, enhance the adsorption of dissociative oxygen, and weaken the 0-0 bonding [44-46]. Second, doped metal atoms can form active sites and intimate bonds $\left(\mathrm{M}-\mathrm{N}_{x}\right)$ more efficiently and boost the ORR activity of the material [23]. Third,
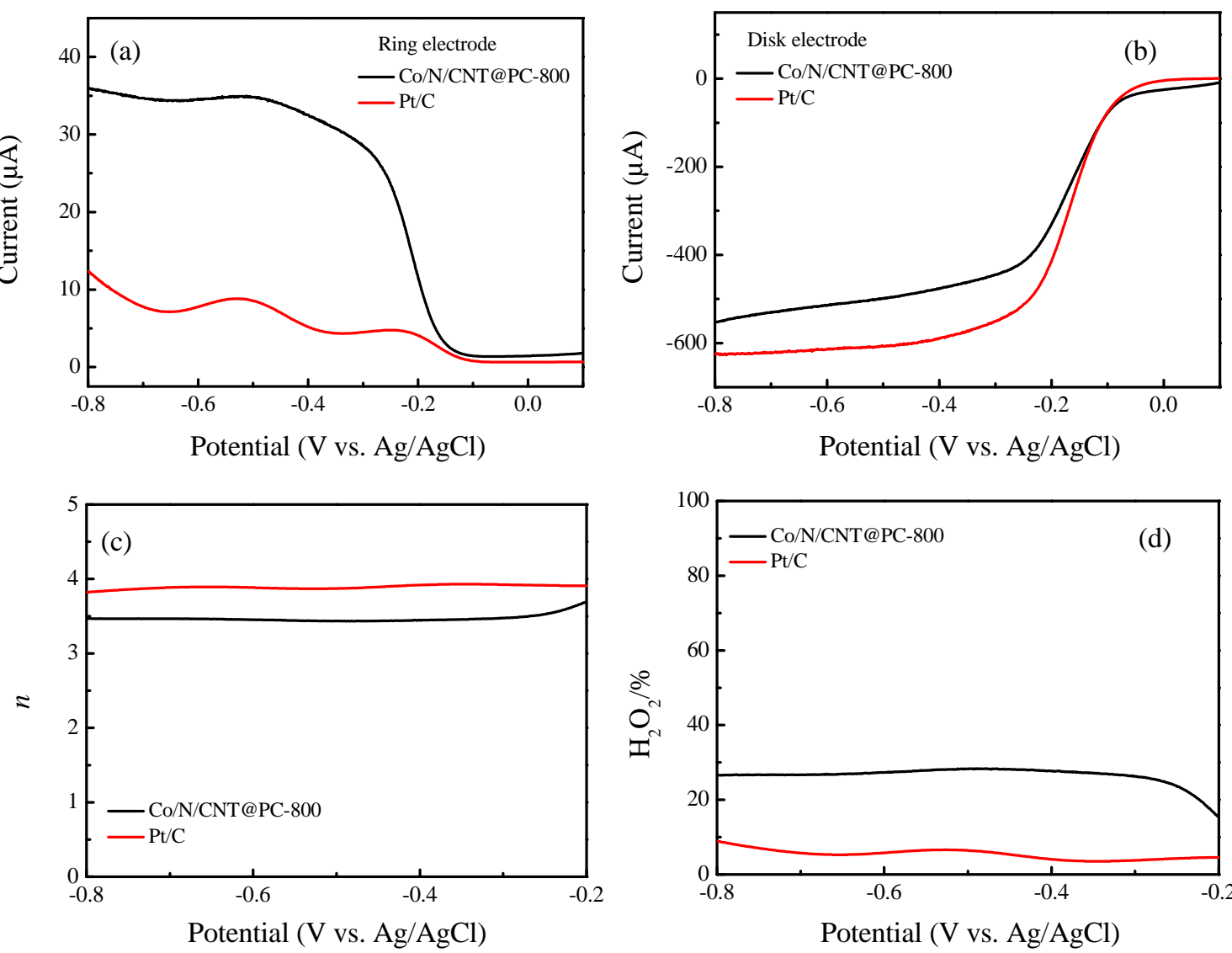

Fig. 7. Ring currents (a) and disk currents (b). Electron transfer number (c) and hydrogen peroxide yield (d) during ORR process of Co/N/CNT@PC-800 and Pt/C catalysts in $\mathrm{O}_{2}$-saturated $0.1 \mathrm{~mol} \mathrm{~L}^{-1} \mathrm{KOH}$ at a rotation rate of $1600 \mathrm{rmin}^{-1}$ with a scan rate of $5 \mathrm{mV} \mathrm{s}$. 
the Co nanoparticles also activated the protective carbon layers, which allowed the carbon layer of the outer surface to participate in the ORR process [28]. Finally, the Co nanoparticles catalyzed the dicyandiamide into CNTs on the surface of the porous carbon, affording more exposed active sites and facilitating the transportation of ORR-relevant species.

\section{Conclusions}

We successfully employed an uncomplicated process that effectively combines the advantages of porous carbon and biomass to obtain catalysts for the ORR. Cheap waste paper was used as carbon source, which was doped with Co and $\mathrm{N}$ to prepare a Co/N/CNT@PC-800 electrocatalyst. The Co and N co-doped carbon material greatly improved the ORR performance. The Co catalyzed the in situ formation of carbon nanotubes, which promoted the exposure of active sites. The porous carbon substrate was favorable for mass transfer. The Co/N/CNT@PC-800 catalyst exhibited excellent ORR activity, a positive half-wave potential, and a quasi-four-electron reaction pathway. The tolerance of methanol and stability of Co/N/CNT@PC-800 was also better than that of commercial $\mathrm{Pt} / \mathrm{C}$. This work will provide a new idea for the use of biomass for the synthesis of low-cost electrocatalysts with effective performance for metal-air batteries and fuel cells.

\section{References}

[1] K. Z. Jiang, P. T. Wang, S. J. Guo, X. Zhang, X. Shen, G. Lu, D. Su, X. Q. Huang, Angew. Chem. Int. Ed., 2016, 55, 9030-9035.

[2] S. Y. Wang, S. P. Jiang, Nat. Sci. Rev., 2017, 4, 163-166.
[3] W. J. Jiang, L. Gu, L. Li, Y. Zhang, X. Zhang, L. J. Zhang, J. Q. Wang, J. S. Hu, Z. D. Wei, L. J. Wan, J. Am. Chem. Soc., 2016, 138, 3570-3578.

[4] S. J. Guo, S. Zhang, L. H. Wu, S.H. Sun, Angew. Chem. Int. Ed., 2012, $124,11940-11943$.

[5] G. M. Jiang, H. Y. Zhu, X. Zhang, B. Shen, L. H. Wu, S. Zhang, G. Lu, Z. B. Wu, S. H. Sun, ACS Nano, 2015, 9, 11014-11022.

[6] C. Cao, L. L. Wei, G. Wang, J. Q. Shen, Nanoscale, 2017, 9, 3537-3546.

[7] D. F. Yan, Y. X. Li, J. Huo, R. Chen, L. M. Dai, S. Y. Wang, Adv. Mater, 2017, 1606459.

[8] D. S. Geng, Y. Chen, Y. G. Chen, Y. L. Li, R. Y. Li, X. L. Sun, S. Y. Ye, S. Knights, Energy Environ. Sci., 2011, 4, 760-764.

[9] L. J. Yang, S. J. Jiang, Y. Zhao, L. Zhu, S. Chen, X. Z. Wang, Q. Wu, J. Ma, Y. W. Ma, Z. Hu, Angew. Chem. Int. Ed., 2011, 123, 7270-7273.

[10] H. T. Wang, W. Wang, Y. Y. Xu, S. Dong, J. W. Xiao, F. Wang, H. F. Liu, B. Y. Xia, ACS Appl. Mater. Interfaces, 2017, 9, 10610-10617.

[11] Y. Z. Zhou, C. H. Yen, S. F. Fu, G. H. Yang, C. Z. Zhu, D. Du, P. C. Wo, X. N. Cheng, J. Yang, C. M. Wai, Y. H. Lin, Green Chem., 2015, 17, 3552-3560.

[12] Z. H. Sheng, H. L. Gao, W. J. Bao, F. B. Wang, X. H. Xia, J. Mater. Chem., 2012, 22, 390-395.

[13] W. H. Niu, L. G. Li, X. J. Liu, N. Wang, J. Liu, W. J. Zhou, Z. H. Tang, S. W. Chen, J. Am. Chem. Soc., 2015, 137, 5555-5562.

[14] Z. H. Xiang, Y. H. Xue, D. P. Cao, L. Huang, J. F. Chen, L. M. Dai, Angew. Chem. Int. Ed., 2014, 53, 2433-2437.

[15] D. S. Yang, D. Bhattacharjya, S. Inamdar, J. Park, J. S. Yu, J. Am. Chem. Soc., 2012, 134, 16127-16130.

[16] K. P. Singh, E. J. Bae, J. S. Yu, J. Am. Chem. Soc., 2015, 137, 3165-3168.

[17] I. Y. Jeon, S. Zhang, L. P. Zhang, H. J. Choi, J. M. Seo, Z. H. Xia, L. M. Dai, J. B. Baek, Adv. Mater., 2013, 25, 6138-6145.

[18] Z. L. Ma, S. Dou, A. L. Shen, L. Tao, L. M. Dai, S. Y. Wang, Angew. Chem. Int. Ed., 2015, 54, 1888-1892.

[19] J. P. Paraknowitsch, A. Thomas, Energy Environ Sci., 2013, 6,

\section{Graphical Abstract}

Chin. J. Catal., 2018, 39: 790-799 doi: 10.1016/S1872-2067(17)62982-6

Paper-derived cobalt and nitrogen co-doped carbon nanotube@porous carbon as a nonprecious metal electrocatalyst for the oxygen reduction reaction

Gaopeng Liu, Bin Wang, Li Xu, Penghui Ding, Pengfei Zhang, Jiexiang Xia*, Huaming Li*, Junchao Qian Jiangsu University, China; Oak Ridge National Laboratory, USA; Shanghai Jiao Tong University, China; Suzhou University of Science and Technology, China

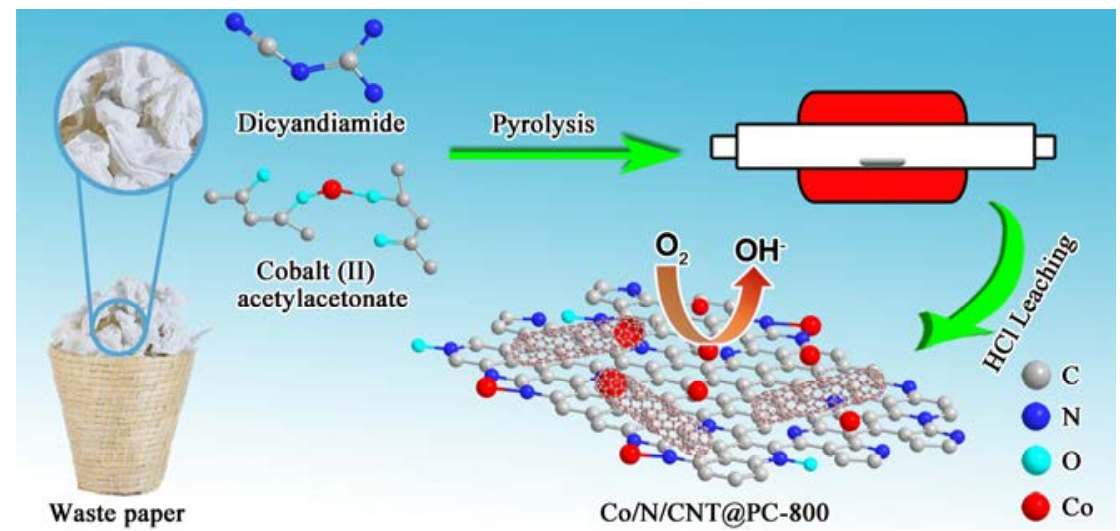

Paper-derived cobalt and nitrogen co-doped carbontube@porous carbon was fabricated as a nonprecious metal electrocatalyst and showed excellent catalytic performance for the oxygen reduction reaction. 
2839-2855.

[20] J. Liu, P. Song, Z. G. Ning, W. L. Xu, Electrocatalysis, 2015, 6, 132-147.

[21] M. Zhou, H. L. Wang, S. J. Guo, Chem. Soc. Rev., 2016, 45, 1273-1307.

[22] J. Masa, W. Xia, M. Muhler, W. Schuhmann, Angew. Chem. Int. Ed., 2015, 54, 10102-10120.

[23] X. Y. Cui, S. B. Yang, X. X. Yan, J. G. Leng, S. Shuang, P. M. Ajayan, Z. J. Zhang, Adv. Funct. Mater., 2016, 26, 5708-5717.

[24] Z. Wang, S. J. Peng, Y. X. Hu, L. L. Li, T. Yan, G. R. Yang, D. X. Ji, M. Srinivasan, Z. J. Pan, S. Ramakrishna, J. Mater. Chem. A, 2017, 5, $4949-4961$.

[25] B. Li, H. Nam, J. Zhao, J. Chang, N. Lingappan, F. Yao, T. H. Lee, Y. H. Lee, Adv. Mater., 2017, 29, 1605083.

[26] H. Y. Yu, A. Fisher, D. J. Cheng, D. P. Cao, ACS Appl. Mater. Interfaces, 2016, 8, 21431-21439.

[27] S. E. F. Kleijn, S. C. S. Lai, M. T. M. Koper, P. R. Unwin, Angew. Chem. Int. Ed., 2014, 53, 3558-3586.

[28] Y. Y. Liu, H. L. Jiang, Y. H. Zhu, X. L. Yang, C. Z. Li, J. Mater. Chem. A, 2016, 4, 1694-1701.

[29] T. Cao, D. S. Wang, J. T. Zhang, C. B. Cao, Y. D. Li, Chem. Eur. J., 2015, 21, 14022-14029.

[30] M. Y. Song, H. Y. Park, D. S. Yang, D. Bhattacharjya, J. S. Yu, ChemSusChem, 2014, 7, 1755-1763.

[31] S. Y. Gao, Y. L. Chen, H. Fan, X. J. Wei, C. G. Hu, H. X. Luo, L. T. Qu, J. Mater. Chem. A, 2014, 2, 3317-3324.

[32] P. Chen, L. K. Wang, G. Wang, M. R. Gao, J. Ge, W. J. Yuan, Y. H. Shen,
A. J. Xie, S. H. Yu, Energy Environ. Sci., 2014, 7, 4095-4103.

[33] J. Wei, Y. Liang, Y. X. Hu, B. Kong, G. P. Simon, J. Zhang, S. P. Jiang, H. T. Wang, Angew. Chem. Int. Ed., 2016, 55, 1355-1359.

[34] Y. Z. Chen, C. M. Wang, Z. Y. Wu, Y. J. Xiong, Q. Xu, S. H. Yu, H. L. Jiang, Adv. Mater., 2015, 27, 5010-5016.

[35] J. I. Jung, M. Risch, S. Park, M. G. Kim, G. Nam, H. Y. Jeong, S. H. Yang, J. Cho, Energy Environ. Sci., 2016, 9, 176-183.

[36] S. G. Wang, Z. T. Cui, M. H. Cao, Chem. Eur. J., 2015, 21, 2165-2172.

[37] D. Mondal, M. Sharma, C. H. Wang, Y. C. Lin, H. C. Huang, A. Saha, S. K. Nataraj, K. Prasad, Green Chem., 2016,18, 2819-2826.

[38] B. Wang, L. Xu, G. P. Liu, P. F. Zhang, W. S. Zhu, J. X. Xia, H. M. Li, J. Mater. Chem. A, 2017, 5, 20170-20179.

[39] Z. J. Liu, Z. H. Zhao, Y. Y. Wang, S. Dou, D. F. Yan, D. D. Liu, Z. H. Xia, S. Y. Wang, Adv. Mater., 2017, 29, 1606207.

[40] B. B. Zhang, J. L. Song, G. Y. Yang, B. X. Han, Chem. Sci., 2014, 5, 4656-4660.

[41] H. L. Jiang, Y. F. Yao, Y. H. Zhu, Y. Y. Liu, Y. H. Su, X. L. Yang, C. Z. Li, ACS Appl. Mater. Interfaces, 2015, 7, 21511-21520.

[42] M. Kuang, Q. H. Wang, P. Han, G. F. Zheng, Adv. Energy Mater., 2017, 7, 1700193.

[43] D. H. Deng, L. Yu, X. Q. Chen, G. X. Wang, L. Jin, X. L. Pan, J. Deng, G. Q. Sun, X. H. Bao, Angew. Chem. Int. Ed., 2013, 52, 371-375.

[44] W. Xia, A. Mahmood, Z. B. Liang, R. Q. Zou, S. J. Guo, Angew. Chem. Int. Ed., 2016, 55, 2650-2676.

[45] L. P. Zhang, Z. H. Xia, J. Phys. Chem. C, 2011, 115, 11170-11176.

[46] X. X. Zou, X. X. Huang, A. Goswami, R. Silva, B. R. Sathe, E. Mikmekov, T. Asefa, Angew. Chem. Int. Ed., 2014, 53, 4372-4376.

\title{
非贵金属钴、氮共掺杂碳纳米管负载纸衍生多孔碳电催化剂的制备 及其氧还原性能研究
}

\author{
刘高鹏 ${ }^{\mathrm{a}}$ ，王 涁 ${ }^{\mathrm{a}}$, 徐 丽 ${ }^{\mathrm{a}}$, 丁鹏辉 ${ }^{\mathrm{a}}$, 张鹏飞 ${ }^{\mathrm{b}, \mathrm{c}}$, 夏杰祥 ${ }^{\mathrm{a}, \mathrm{b},{ }^{*}}$, 李华明, ${ }^{\mathrm{a}, \# \text {, 钱君超 }}{ }^{\mathrm{d}}$ \\ a江苏大学化学化工与能源研究院, 江苏镇江212013, 中国 \\ b橡树岭国家实验室化学科学部, 橡树岭37830, 美国 \\ c上海交通大学化学化工学院, 上海200240, 中国 \\ d 苏州科技大学江苏省环境功能材料重点实验室, 江苏苏州215009, 中国
}

摘要: 燃料电池可以直接将化学能转化为电能, 是一种极具前景的能量转换设备. 目前, 铂碳是燃料电池阴极氧还原反应 (ORR)常用催化剂, 但是铂储量低、价格昂贵、稳定性差且容易受 $\mathrm{CO}$ 毒化, 极大地限制了其在燃料电池商业化中的应用. 因 此, 探索价格低廉、性能优越的非贵金属氧还原催化剂显得尤为重要.

大量研究发现, 碳基材料具有优越的氧还原性能和良好的电化学稳定性. 同时, 自然界的生物质种类丰富, 是很好的 碳基材料来源. 本文选取日常生活中最常见的富碳生物质废纸作为碳源, 二氰二胺和乙酰丙酮钴分别作为氮源和钴源, 经 过特定气氛下的梯度升温制得非贵金属钴、氮共掺杂碳纳米管负载多孔碳氧还原催化剂(Co/N/CNT@PC-800). 考察了杂 原子 $\mathrm{N}$ 掺杂、过渡金属Co掺杂对材料形貌和性能的影响, 采用扫描电子显微镜(SEM)、透射电子显微镜(TEM)、X射线衍射 (XRD)、拉曼(Raman)光谱、氮气吸附-脱附和X射线光电子能谱(XPS)等表征方法探究了Co/N/CNT@PC-800材料的组成与 结构, 通过循环伏安法(CV)以及线性扫描伏安法(LSV)等电化学测试探究了其氧还原反应性能.

SEM和TEM结果表明, Co/N/CNT@PC-800材料为表面生长着大量碳纳米管的多孔碳结构. 这是因为二氰二胺和钴引 入后, 钴催化二氰二胺转化成碳纳米管. 金属纳米粒子被封装在碳层之间和碳纳米管中而得到有效的保护, 使之不易被酸 腐蚀. 同时, Co 和 N元素可以形成更多的活性位点 $\left(\mathrm{Co}-\mathrm{N}_{\mathrm{x}}\right)$, 增强材料ORR活性. SEM和氮气吸附-脱附结果显示, 掺杂Co后, 材料的介孔结构会进一步增加, 形成微孔/介孔结构. 多孔结构可以增强ORR相关物质 $\left(\mathrm{O}_{2}, \mathrm{H}^{+}, \mathrm{OH}^{-}, \mathrm{H}_{2} \mathrm{O}\right)$ 的传质速率, 提升 反应速率, 达到增强ORR活性的效果. 除此之外, 多孔的结构也可以促进活性位点的暴露, 进而提升材料的ORR性能. XPS 结果显示, Co/N/CNT@PC-800材料中N主要以吡啶氮和石墨氮两种形式存在, 而这两种类型的氮有利于促进ORR的进行. Raman光谱结果显示, 在引入 $\mathrm{N}$ 和Co元素后, 材料的缺陷结构有所增加, 因而有利于电催化氧还原反应性能的提升.

另外, LSV 测试结果表明, 在引入Co或者N后, 材料催化ORR的起始电位、半波电位、极限电流密度均有小幅改善; 同 
时引入Co和N后, Co/N/CNT@PC-800材料催化ORR的起始电位(0.005 V vs. Ag/AgCl)、半波电位 $(-0.173 \mathrm{~V} v \mathrm{vs} . \mathrm{Ag} / \mathrm{AgCl})$ 、 极限电流密度 $\left(-4.117 \mathrm{~mA} \mathrm{~cm} \mathrm{~cm}^{-2}\right.$ )均有较大幅度的改善. 通过Koutecky-Levich (K-L)方程计算以及旋转环盘电极测得的氧还 原极化曲线结果均表明, Co/N/CNT@PC-800材料的氧还原反应是通过准四电子反应转移路径进行. 此外, 循环(3000圈 CV)稳定性测试结果证明, Co/N/CNT@PC-800材料比商业化的Pt/C具有更好的稳定性.

总之, 本文采用简单的梯度升温法制备出非贵金属钴、氮共掺杂的碳基氧还原催化剂(Co/N/CNT@PC-800), 为探索利 用生物质制备电催化剂用于燃料电池提供了一种可供选择的途径.

关键词: 氧还原反应; 废纸; 生物质; 多孔碳; 钴

收稿日期: 2017-11-21. 接受日期: 2017-12-23. 出版日期: 2018-04-05.

*通讯联系人. 电话: (0511)88791108; 电子信箱: xjx@ujs.edu.cn

\#通讯联系人. 电话: (0511)88791108; 电子信箱: lhm@ujs.edu.cn

基金来源：国家自然科学基金(21476098, 21471069, 21576123); 博士后国际交流计划(20150060).

本文的电子版全文由Elsevier出版社在ScienceDirect上出版(http://www.sciencedirect.com/science/journal/18722067). 